\title{
HET OOST-INDISCHE SACSPIEGELTJE (1684)
}

\author{
MEDEGEDEELD DOOR
}

DR. J. DE HULLU.

De Directie van Bengalen heeft onder het bestuur der OostIndische Compagnie op het stuk van de eerlijkheid en goede trouw harer dienaren een uiterst slechten naam gehad. De Graaff, Bogaert, Valentijn, zij gewagen allen van de ongerechtigheden, die daar in hun tijd, het laatst van de zeventiende en het begin van de achttiende eeuw, werden bedreven '. Valentijn verklaart iemand te hebben gekend die, atoen hij op Batavia kwam aan zeker heer van den eersten rang 10.000 rijksdaalders, zoo men zeide, schuldig was, en die niet kunnende betalen in deze hoedanigheid van directeur na Bengalen gezonden en daardoor in staat gesteld wierd om in zeer weinig jaren niet alleen die schuld te vereffenen, maar ook om bij zijn overlijden, nog een somme van 300.000 rijksdaalders na te laten. Men zegt (schrijft hij) dat hier ${ }^{2}$ onderkooplieden en boekhouders zijn geweest, die schepen van 2 a 300 lasten $^{3}$ op hun beurs hielden en onder den naam van Denen enz. na de Maldives ${ }^{4}$ zonden ${ }^{5}$. Zoo zeer nam van lieverlede het kwaad toe dat het de Vergadering van Zeventien in een brief aan den Gouverneur-Generaal Mossel in 1754 de bittere klacht ontlokte: let men op een directie als die van Bengalen, «zoo nabij de hoofdplaats ' en zoo immediaat onder deszelfs bestier en toezicht gelegen, zoo bevindt men dezelve bij een successie van directeuren sedert een lengte van jaren schuldig aan de enormste uitstappen en morserijen ?,

1 Zie mijn opstel: De matrozen en soldaten op de schepen der Oost-Indische Compagnie, in deze Bijdragen Dl. 69 blz. 350-356, en Valentijn, V blz. 176 vlg.

$2 \mathrm{Nl}$. in Bengalen.

3 400 à 600 ton.

- De Maladiven-eilanden.

5 Valentïn, $\nabla$ blz. 176.

- Batavia.

7 Knoeierijen met het drijven van particuliercn handel. 
's Compagnie's effecten ' en belangen als roofgoed behandelende, de inkoopprijzen der goederen willekeurig en door de gerafineerdste practijken cargeerende ${ }^{2}$, en onze uitdrukkelijke ordres en reglementen omtrent den inkoop der lijnwaden en andere goederen zonder het minste regard op eed of plicht op de criantste wijze violeerendes 3 .

Hetgeen de aangehaalde schrijvers met enkele staaltjes vermelden en door de Heeren Zeventien in algemeene termen wordt aangewezen, vindt men in het hierachter afgedrukte "Oost-Indische Sacspiegeltje, tot op den grond toe blootgelegd. Wie het heelt opgesteld is onbekend ${ }^{4}$ - de auteur heeft 2 ijn naam verzwegen doch uit den tekst zelf mag men beshuiten dat hij een oud-dienaar van de Compagnie was, men zou haast zeggen een, wien zijn loopbaan velerlei teleurstelling en miskenning had bereid en die, omstreeks 1684 in het Vaderland wedergekeerd, de pen heeft opgevat om de schendige stukken daar ginds door hem aanschouwd wereldkundig te maken ${ }^{5}$. Uitgaande van Bengalen houdt hij zijn lezers den toestand aldaar voor oogen als tot een spiegel van wat allerwege op de Indische Compagniescomptoiren viel te zien.

Den oorsprong van het bederf, waardoor het gansche lichaam van de Compagnie in Indië was aangetast, zoekt hij in den particulieren handel, waar zich al haar dienaren aan schuldig maakten, om het even of zij hooggeplaatst waren of lagere rangen bekleeden, het euvel, dat haar ondermijnde van ouds, dat $z$ ij door middel van verordeningen zonder tal trachtte uit te roeien ${ }^{\circ}$, maar dat onverpoosd bleef voortwoekeren vermits diegenen zelf, wien de handhaving van de verordeningen was toebetrouwd, ze uit baatzucht of niet of op het allerslapst ten uitvoer legden.

« Geen middelen, aantijgingen noch plakkaten zijn krachtig genoeg (aldus schrijft een reiziger in den aanvang der achttiende eeuw) om dien (particulieren) handel te beletten, zoolang de fiscalen der Indische comptoiren zichzelven daarmede

1 Goederen.

- Te hoog in de rekeningen van de boeken brengende.

- Rescriptie van de Zeventien aan Mossel in antwoord op zijn Bedenkingen over den intrinsieken staat der Compagnie, 28 Maart 1754.

- Evenmin blijkt voor wie hij zijn geschrift heeft bestemd.

s Ofschoon op het stak zelf sta2t aangeteekend „overgecomen 1684", blijkt uit den tekst duidelijk genoeg dat het door den auteur na zijn terugkomst in het vaderland is geschreven.

- Zie mijn reeds aangehaald opstel over de matrozen en soldaten blz. 349 . 
bemoeien en de glans van bet goud meer vermogen op hun gemoederen heeft dan eed en plicht, zijnde dezelve doorgaans de voornaamste opkoopers der goederen welke door de scheepsvrienden aangebracht worden"'.

Voor iemand, die zich met eigen oogen had kunnen overtuigen dat zulke maatregelen in de practijk niet het minste uitwerkten, behoorde er waarlijk een onverstoorbaar optimisme toe om van de "remediën", welke hij voorsloeg, nog eenige verbetering te wachten. Het groote middel tot genezing, afschaffing van het monopoliestelsel der Compagnie, lag klaarblijkelijk, evenals bij de meesten van zijn tijdgenooten trouwens, ver buiten zijn gezichtskring.

Hoe belangwekkend de onthullingen van het Sacspiegeltje ook zijn, het spiegelt slechts één zijde af van het beeld, de Indische, van den Vaderlandschen kant geeft het niets te aanschouwen. Toch lagen de oorzaken van den achteruitgang der Compagnie niet in Indië alleen, maar insgelijks, ja meer nog wellicht in Nederland, bij de Bewindhebbers zelf.

Was hun toezicht, tot wering van het overbrengen van particuliere goederen in cle Vaderlandsche havens gehouden, veeltijds niets dan een ijdele comedievertooning ${ }^{2}$, al even slap kweten zij zich van andere plichten, die aan hun opperbestuur waren verknocht. Om zich van hun tekortkomingen op het stuk eenig denkbeeld te kunnen vormen, heeft men slechts het belangrijk vertoog op te slaan, omstreeks 1755 door Thomas Hope samengesteld en van wege zijn medehoofdparticipanten in datzelfde jaar ingediend bij de Haagsche Besognes ${ }^{3}$. Daar was om te beginnen de handel, dien de Compagnie van hier op Indie dreef, bestaande in het verzenden derwaarts van zoogenaamde Vaderlandsche goederen, goud, zilver en meer van dien aard. Waarom, zoo wordt in het vertoog gevraagd, waarom hebben

\footnotetext{
1 Abraham Bogaert, Historische reizen door d'Oostersche deelen van Asia, Amst. 1711, blz. 422.

- Zie mijn aangehaald opstel over de matrozen en soldaten, blz. 352-354.

3 Praeadvies van de hoofdparticipanten over den zorgelijken staat der Oost-Indische Compagnie, ingevolge resolutie Zeventien van 20 Maart 1754 in 1755 ingediend aan de Haagsche Besognes, en blijkens een aanteekening van den advocaat der Compagnie Cornelis van der Hoop opgesteld door den hoofdparticipant Thomas Hope. De Haagsche Besognes waren een bijzondere commissie uit de Heeren Zeventien, die in Den Haag jaarlijks placht samen te komen om de overgekomen Indische brieven te lezen en de antwoorden daarop te ontwerpen.
} 
de Bewindhebbers er niet altoos hun eerste zorg en werk van gemaakt en bij de presidiale' Kamer ter hand genomen om simmediaat na het arrivement der Indische negotie- en administratieboeken, dewelke niet bedriegen kunnen wanneer(zij) met behoorlijke kennisse en discernement doorbladerd, worden, sieder project van schip of schepen nevens alle de andere deelen van 's Compagnie's wijduitgestrekten handel en verdere belangen onder de Indische administratie ressorteerende, te overwegen en te onderzoeken? Dit ware, naar hun oordeel, beter geweest dan zich te bepalen bij shetgeen de Indische brieven in het geheel niet of kwalijk voordragen of wel bij deze Haagsche Besognes somtijds in het geheel niet gehoord dan wel averechts begrepen wordt». Dat behoorde ide ziel en het eenige oogmerk van Uwe sessiën bij deze gewichtige deliberatiën te zijn geweest (voegen de hoofdparticipanten de Bewindhebbers toe), of is het van geen belang altoos of in deze jaarlijksche Indische projecten, dewelke zoo vele millioenen importeeren, den dienst van de Compagnie dan wel het particuliere belang van hare ministers en dienaren dan wel deszelfs ruine werkzaam is geweest?, Waarom heeft men niet altoos voor een vasten regel gehouden $\mathrm{om}$ alle de petitiën ${ }^{2}$ van Indië, niet alleen van handelswaren maar ook van ammunitie, equipage ${ }^{3}$ en alle andere soorten van behoeftens, te onderzoeken, en niet eerst na voorafgaande overweging zoowel van de ware gesteldheid van den verkoop dier handelswaren als van het gebruik dier behoeften over de voldoening van ieder artikel beslist? Immers heeft men daartoe alle de noodige bescheiden en meer dan bekwamen tijd bij de presidiale Kameren in handen? Waarom heeft men sintegendeel bij de deliberatiën over de voldoening, van deze petitiën "veelal geen andere geest zien werken dan die van kibbelen en krakeelen onder de respectieve Kameren alleen over de verdeelingen 4 of wel van een algemeen genoegen wanneer er maar veel te verdeelen viels. Ook zouden de Indische

1 De Kamer, die in de Vergaderingen vnn de Zeventien presideerde, wat om de beurt zes jaar achtereen door die van Amsterdam en de volgende twee jaren door die van Zeeland geschiedde.

- Aanvragen, bestellingen, gewoonlijk Eischen genoemd.

3 Scheepsbehoeften.

- De leveranties van de door Gouverneur-Generaal en Baden uit Patria gedane Eischen voor Indië plachten door de Vergadering van Zeventien jaarlijks over de verschillende Kamers verdeeld te worden. 
ministers wel tot verantwoording dezer «erroneuse Eischen» kunnen aanvoeren, dat $z \mathrm{ij}$ "meer handelswaren en meer behoeften van alle soorten gepetitioneerd hadden als van beide voor 's Compagnie's dienst convenieerde, alleen met dit politieke oogmerk om zich in de gunst van deze en diergelijke zwakheden te ingratiëeren en daardoor hunne personen recommandabel te maken, , immers zoo hier te lande als in Indië weet men stot welke eindens meestal ten dekmantel het specieuse pretext van het provinciale en stedelijke belang gebruikt wordt, '.

\footnotetext{
1 Een sterk sprekend staaltje van het in den tekst aangeroerde staat opgeteekend in de ${ }_{n}$ Consideratiön nopens eenige importante excessen welke in Nederland concerneerende het generale maniëment der zaken van de Generale Nederlandsche geoctroijeerde Oost-Indische Compagnie tot nog toe reëel en wezentlijk subsisteeren enz." van circa 1750: "ter Kamere van $\mathbf{M}$ (iddelburg) in $\mathbf{Z}$ (eeland) waar men verzekert dat nog heden ten dage permanent plaats heeft, dat in plaatse van de respectieve koopmanschappen en verdere benoodigdheden voor rekening van de Compagnie ten minsten prijze publiek aan te besteden of in te koopen, men ter contrarie daarvan maakt praerogatieven voor deze en gene favorieten en dezelve goederen geheel contrarie werden geleverd, bijvoorbeeld d' heer...., die gefavoriseerd en gequalificeerd was tot een $\mathrm{kwart}$ in de leverantie van de benoodigde hennep en $v a n$ de advancen (winsten) daarop permanent acquireerende moeste vitdeelen aan .... en deszelfs zuster $f 600$, wierd geordonneerd aan dezelve nog $f 300$ boven dien te geven, en als hij zich deswegens wat te extravagant expliceerde en daarbenevens zijn onwilligheid te kennen gaf, wierde hem verzekerd dat hij nog circa $f 700$ à $f 800$ over hadde; dus die voorzeide winste op $f 750$ voorondersteld wezende en die gevoegd bij de voorzeide $f 900$, zoo consteert dat de Compagnie te veel betaalde op een kwart in voorzeide leverantie $f 1650$, zijnde op één eenig artikel van benoodigdheden voor ' $t$ geheel $f 6600$ jaarlijks meer dan die bij een observantie van menage (zuinigheid) te bekomen was. In plaats van een publieke aanbesteding der leveranties observeert men in genoegzaam alle de departementen deze dus lange gepraedomineert hebbende en voor de interessanten maar alleene plausibele maximes, hierop uitkomende: dat de leverantiën, welke moeten worden gedaan, in ieder departement werden gepartageert (sic) in vier gelijke deelen, teneinde met een ieders aandeel hunne familiën (te) favoriseeren, opdat dezelve daardoor mochten in staat zijn zoodanige ruime uitkeeringen te doen als hiervoren proportioneerd (sic) van de hennep is geremarkeerd, en derzelver families daardoor niet alleen prodigaal zouden kunnen en mogen subsisteeren maar nog daar te boven prospereeren voor een kwaden tijd, op dit authoratieve doch reëel frivool en exorbitant praetext dat de Compagnie is gesticht voor de steden en leden en dat de grootste interessanten (belanghebbenden als actiehouders) zijn de Joden. Deze scurriele (belachelijke) exceptiën die velen als plansibel en industrieus considereeren, maken het reëele causa movens uit waarom men heeft gezien exempelen dat deze en gene consciëntieuse leverantiers de goederen, die men hun toebedeeld hadde aan de Compagnie te leveren, wat te mediocre in prijs hadden gesteld, derzelver rekeningen heeft gelaten onvoldaan omdat ze de prijzen te laag gesteld hadden en al te zeer kwamen (te) discordeeren met die der bevorens gedane leverantiön, welke veel hooger waren gedeclareerd, teneinde om door dat middel alle presumptiën van differentie te eviteeren".
} 
Verder werpen de hoofdparticipanten de vraag op of het opperbewind in het Vaderland niet mede verantwoordelijk is voor de nadeelen, aan de Compagnie toegebracht door de in Indië gepleegde "malversatiën.. Zij erkennen dat er morserijen en malversatiën door de Indische dienaren worden gepleegd, sal zijn (zeggen zij) de corpora delicti juist niet zooverre af als in Indië gelegen,, welke geen menschelijke vermogens kunnen verhoeden of voorzien zelfs, edoch het zijn, naar hun oordeel, niet deze, die de Compagnie tot aden tegenwoordigen staat van zorgelijkheid, hebben gebracht of die zij op het oog hebben. $Z_{i j}$ hebben alleen het oog op zaken, welke de opperdirectie in Nederland bij een minder gebrekkig bestier had kunnen verhinderen. Om een voorbeeld te noemen, 'met wat gevolg of effect zou het comptoir van Bengalen (dus vragen zij) het ooit daarop hebben kunnen toeleggen om de gewone avancen ${ }^{1}$ op het Vaderlandsch zilver te verduisteren zooals Uwe retroacta zeggen?, -Immers geen andere dan die van haar eigen confusie, indien deze supreme directie niet verzuimd had om de Indische administratieboeken en verdere verantwoordingen dewelke men te dien einde alle jaren van daar laat overkomen, te examineeren, onderzoeken en te bearbeiden, en eenvoudiglijk getoetst had, aan den algemeenen grondregel edat de koers zoowel van het goud en zilver als van alle soorten van specie» door de dienaren aldaar "moest verantwoord worden conform de Indische valuatiën van oude tijden af in Uw eigen boeken geintroduceerd. Had de ssupreme directie, hier te lande de eerste maal dat de Bengaalsche ministers nalieten "volgens de geroerde gronden de verantwoordingen van deze speciën conform de door Uwe praedecesseuren geëtablisseerde valuatiën te doen, onmiddellijk 'de noodige voorziening daartegen gedaan en deze enorme morserijen , naar behooren "gecensureerd, zoo had de Compagnie "noch deze schade noch hare autoriteit deze atteinte geleden, > doch nu men dit liet loopen, werd noodwendig een deur geopend voor alle andere soorten van excessen.

De Indische boeken, welke jaarlijks van de ssubalterne comptoiren, komen, zoo merkt het vertoog op, skunnen aan deze inconveniënten " niet 'remedieeren, vermits alle dezelve, behalve de Bataviaasche boeken alleen, op een wijze geconstitueerd zijn dat zij - niet den handel zelf zooals hij daar te lande gedreven

1 Voordeelen, winsten.

Dl. 76. 
en gegireerd wordt nevens den ontvang en uitgave der cassa openleggen, maar alleen een sommiere samentrekking vertoonen hoe veel of hoe weinig in één massa op beide, Vaderlandsche en Indische, koopmanschappen gewonnen dan wel voor verlies afgeschreven is .

Er was nog meer, meenden de hoofdparticipanten, dat de aandacht vergde. De Heeren Zeventien hebben het weleer zoo begrepen, dat «het gedrag en de conduites van 's Compagnie's zeevarende dienaren niet geacht zouden worden verantwoord te zijn vóórdat sunne scheepsjournalen, dewelke men in meest alle opzichten als hunne negotie- of administratieboeken kan aanmerken prealabel met de gestatueerde zeilorders geconfronteerd en daarmede conform bevonden waren". Hoe, vragen zij, hoe is dan mogelijk dat diezelfde Heeren Zeventien zoodanig onderzoek van het gedrag en de administratie hunner negotiëerende dienaren achterwege laten, ofschoon van veel meer gewicht? «Of moeten wij de redenen van deze incongruiteiten en tegenstrijdigheden, beide in dit geval en in oneindige andere van veel minder belang, waaromtrent ten minsten een exterieur van een zeer scrupuleuze attentie vertoond wordt, elders zoeken? En wel hierin dat men het examen van het gedrag en de conduites nevens de verantwoordinge van 's Compagnie's zeevarende dienaren door daartoe aangestelde examinateurs kan laten verrichten, maar dat die van het gedrag en de administratie der negotiëerende in het geheel niet geschiedt omdat dit juist van het ressort van het opperbewind is, en aan geen vaste regelen te binden veel $\mathrm{min}$ bij eenige permanente instructiën te bepalen of te begrijpen uit hoofde van de dagelijksche veranderingen of revolutiën, waaraan het mercantiele wezen gedurig onderhevig is, alleen door een lang. durige en dagelijksche waarneminge kan gesuppleerd worden ? $\$$

Zelfs hebben, aldus vervolgen de vertoogers, de Staten-Generaal dit punt van de oprichting der Compagnie af zoo noodig geoordeeld voor haar instandhouding, dat $z \mathrm{ij}$ shet examen aan geen anderen dan de participanten zelven en dit wel ten overstaan van heeren gedeputeerders uit den haren hebben willen toevertrouwen» en wijders nog en als het ware ten overvloede "noodig en noodzakelijk geoordeeld het gequalificeerd hoofdparticipant-

1 De eoht achttiendeeeuwsche omslachtigheid van schrijftrant, de deftigheid van stijl gelijk men dat toen noemde, had te nauwernood de verwijten aan de Bewindhebbers op vinniger toon kunnen uitdrukken dan hier geschiedt. 
schap ', in imitatie van eertijds het censoraat bij de Romeinen, ingesteld, om boven en behalve het periodiek examen van de boeken en rekeningen der respectieve Kamers ook omtrent derzelver dagelijksche huishouding alle volkomen gerustheid (te) mogen hebben, dat de Compagnie voortdurend "geconserveerd, zoude blijven, ja de Zeventien zelve hebben «zich op het gedrag en de administratie van hunne respectieve Kameren niet willen verlaten zonder een diergelijk periodiek examen van heeren commissarissen uit den haren». Hoe, vragen zij, hoe is dan te verklaren iets daarmede $z 00$ onbestaanbaars "dat 's Compagnie's ministers een meerdere, laat staan zoo een volkomen, fiducie komen te meriteeren van wegens de Heeren Bewindhebberen?, Heeft men van de eerste oprichting der Compagnie ageen vertrouwen in menschen van wat rang of staat hoegenaamd willen - hazardeeren, hoe komen deze 's Compagnie's Indische ministers en dienaren dan aan een 200 gewichtige en nadenkelijke possessie ? Zeker niet op eenige goede gronden, swant zoo wij ons niet bedriegen worden er niet zeer velen over 's Compagnie's belangen in Indië geplaatst, dewelke UEdel.Achtbaren over derzelver particuliere belangen zouden verkiezen te stellens.

Wat voorts den handel betreft van Indië op Nederland, stellen de hoofdparticipanten voorop dat de bestellingen van hier uit Indië gedaan, de zoogenaamde Eischen van retouren, wel verre van "door den arbeid en ervarenisse van deze supreme directie, te worden opgemaakt, het werk zijn s van kooplieden geheel buiten de Compagnie, in de bijzondere koopmanschappen handelende, alsmede ook van makelaars, dewelke niet alleen de Eischen formeeren zelfs met denotatie bijvoorbeeld hoe iedere lading thee in China geassorteerd moet worden - de eenvoudigste zaak die er te bedenken is - maar ook opgeven welke remarques en consideratiën er op de vorige voldoeningen ${ }^{2}$ te maken zijn,

1 De beëedigde of gequalificeerde hoofdparticipanten werden ingesteld in 1623, zij waren negen in getal en werden gekozen uit de hoofdparticipanten, d. i. diegenen van de aandeelhouders. die evenvepl actiën bezaten als voor het Bewindhebberschap werden vereischt $\mathrm{Zij}$ hadden zitting bij het afleggen der generale rekeningen van de administratie der Compagnie, dat sedert het octrooi van 1647 om de vier jaar geschieden moest, ten overstaan ook van de afgevardigden uit de Staten-Generaal; zij moesten verder door de Bewind. hebbers gehoord worden in alle voorvallende zaken van gewicht, waartoe zij zitting verkregen in de vergaderingen der Zeventien.

- De bezendingen ait Indië ter voldoening van de uit het Vaderland derwarts gezonden Eischen. 
dewelke dan, op deze wijze geconstituëerd, door de Vergadering van Zeventien naar Indië worden gezonden,. Echter, zoo gaat het vertoog voort, moet uit dit algemeen bekende feit niet worden afgeleid, dat adit gedeelte van het opperbewind aan de gedachte kooplieden is gedefereerd geworden en door hen bestierd wordt. Neen, ook in dit geval zijn het de Indische dienaren, welke oook over dit gedeelte van 's Compagnie's belang het opperbewind willekeurig exerceeren", althans zoo meenden de hoofdparticipanten te moeten besluiten uit de orders van de Zeventien naar Indië. Neem, bevoorbeeld zeggen $z \mathrm{ij}$, den brief van de Zeventien van 4 September 1739, alwaar dezen zich naar aanleiding van eenige verschillen tusschen genoemde kooplieden en de dienaren in Indië aldus uitlaten: cook moeten de ministers ${ }^{1}$ al dat schrijven, al die klachten en al die raisonnementen niet aanzien als van ons voortkomende, maar zij komen voort uit den mond en opgave der koopluiden, die mogelijk somtijds geen kennisse genoeg hebben om van al onze omstandigheden der negotie en fabrieken met relatie tot Indië te kunnen oordeelen». Zulke ¿favorabele testimoniën en recommandatiën» van Heeren Zeventien cop hunne consideratiën en remarques op het gedrag en de administratie van 's Compagnie's Indische ministers «zouden deze kooplieden, als $2 \mathrm{ij}$ hun bekend waren, zeker vreemd in de ooren klinken (aldus merkt het vertoog bijtend op) doch zij zouden er zich aan den anderen kant niet langer over behoeven te verwonderen, edat hunne Eischen en remarques op de voldoeningen zoo weinig effect sorteeren, zooals dagelijks het onderwerp van Uwe en hare klachten is", maar wat erger is, welke "ruineuse gevolgen, moet voor de welvaart der Compagnie szulk een complicatie van contradictiën en incongruiteiten , hebben, zulk , een prostitutie van 's Compagnie's wettige autoriteit aan haar eigen ministers en dienaren, bij wie ten minste een zekere graad van eerbied en subordinatie behoort gemaintineerd te worden,, vragen de hoofdparticipanten. Immers moeten de Indische ministers op het ontvangen van zulke brieven wel vragen: sindien deze

1 Nl. die in Bengalen. Dezen waren door de Zeventien in den Eisch van retouren voor het jaar 1737 duchtig onder handen genomen om hun wanbeleid. Zij hadden zich daarop in hun brief van 20 Maart 1737 bij GouverneurGeneraal en Raden beklaagd, dat de Zeventien han zooveel ten laste legden. Naar aanleiding van die klachten, door Gouverneur-Generaal on Raden weder naar Nederland overgebriefd, schrijven nu de Zeventien de in den tekst aangehaalde woorden. 
kooplieden in dit noodzakelijk requisiet», namelijk genoegzame kennis om van alle omstandigheden der negotie en fabrieken met relatie tot Indië te kunnen oordeelen, sbeide onkundig zijn en onbedreven, wat mogen dan toch de redenen wezen dat van de zijde der Heeren Bewindhebberen aan dit gebrek, dat immers een notoire imcompetentie komt te impliceeren, niet gesuppleerd wordt? Of mankeert het onze Heeren en Meesters ook aan dezelve kennisse en ervarenisse van 's Compagnie's handel met relatie tot Indië? Zoo ja, en dat wij ons aan al die klachten en al die raisonnementen van die kooplieden niet moeten storen, dan moeten wij het eens voor al daarvoor houden, want geen andere constructie is daarop te maken dan dat dit het uitdrukkelijk begeeren onzer opperheeren is, dat wij ministers, ook over dezen tak van Compagnie's handel evenzeer als over dien tusschen de Indische comptoiren onderling en dien van uit het Vaderland op Indië shet opperbewind naar onze begrippen en naar onze zinlijkheid moeten exerceeren.

Het is dan ook sin den boezem van dit Nederlandsche opperbewind, 200 luidt de slotsom van het vertoog, dat de eerste oorzaken van 's Compagnie's verval opgesloten liggen; (dominium eminens zoo luisterrijk anders en voortreffelijk, is door de supreme Nederlandsche directie, afgestaan en overgegeven aan 's Compagnies dienaars, aan luiden ten prooi gelaten die in Uw eigen retroacta met de zwartste en hatelijkste koleuren staan afgemaald.

De kwaal, door den auteur van het Sacspiegeltje omtrent zeventig jaar te voren waargenomen, had èn in Indië ên in het Vaderland het sloopingswerk onafgebroken voortgezet: toen Hope zijn vertoog aan de Haagsche Besognes aanbood, lag de Compagnie doodziek ter neder. Welhaast kwam zich de eene dokter na den anderen aan haar sponde vervoegen om den veegen toestand van de patiënte op te nemen en zijn meening ten beste te geven over hetgeen er gedaan en gelaten behoorde te worden tot haar herstel. Vruchteloos echter. De ssupreme directie, considereerde en delibereerde zonder eind maar liet de kranke ongeholpen voortsterven; $\mathrm{zij}$ vergat de spreuk der Ouden: «virtutis laus omnis in actione consistit. 
Omme de voornaamste practijcken, die veele heeren gesaghebberen in Indiën tseedert 18 à 20 jaaren hebben gebruuckt ende door haar onderhoorigen tot haar eijgen voordeel meede hebben laaten doen, eens cort aen te wijsen, sullen wij alleen spreecken van Bengaale, als wanneer de resteerende gouvernementen, directiën ende andere gesaghebberiën sich selve sullen ontdecken, mitsgaders eenige opmerckingen omme dit alles te cunnen teegengaan en verbeeteren.

Als een gesaghebber in Bengale comt gaat hij ten eersten snuffelen naar sijn voordeelen, daartoe hem van de ordinaire heijdenen Siawiswas, Sonderdas en Diepsienta, ofte die in haar plaats mochten gekooren werden, met alderleij voorslaagen aenleijding genouch gegeven wert. Deese lieden werden door die heeren gebruuckt omdat sij in regten bij ons geen geloof meriteeren en bij quaden uijtslag geen swaerigheijt er van te verwagten hebben.

Van den vercoop der coopmanschappen van d'Edele Compagnie. Teerste voorval van gewichte is, als de coopmanschappen van de Compagnie moeten vercogt werden, wanneer den heer directeur de voornoemde heijdenen bij hem alleen ontbiet omme tsaamen op het behendighst te overleggen tot wat prijsen die waaren op haar naamen als cooplieden in den openbaaren Raat dienen ingecogt te werden, om op de binnenplaatsen een merckelijke winst voor den directeur te connen opwerpen, daervan sijlieden een gemeene provisie voor haar bedingen. Dit wert alles beschikt door Siawiswas, die als maackelaar overal in ageert.

Daarop volght een bijeenrueping van den Ouglisen Raadt door den heer directeur, die ordinaris bestaat uijt den voorseijden directeur, de .... ${ }^{1}$ persoon, sijnde oppercoopman en negotiebouchouder, fiscaal, pachuusmeester, guastos- of oncosthouder van de logie, cassier en secretaris, die alle met die bedieningen door den selfden heer sijn begunstigt en soo sijt wel maacken tot hooger ampten staan bevordert te werden. Wanneer sij nu

1 Oningevuld gelaten, versta de tweede persoon der directie of secunde. 
bij makckanderen sitten wert door den secretaris een welingestelt gebedt naer de ordre van d'Edele Comp ${ }^{\text {ie }}$ voorgeleesen omme des Heeren seegen over deselve negotie af te bidden. Dan doet den directeur een voorstel, dat de voornoemde coopmanschappen van meester dienen te veranderen ten meesten voordeele van d'Edele Compagnie opdat de Eijschen voor 't Patria en gans Indiën intijts mogten versorgt werden etc. Daarop werden de voornoemde drie heijdenen binnengeroupen, verschijnende Siawiswas als maackelaar, Sonderdas en Diepsienta als cooplieden, dewelcke door den president onder een geveinst praatje tot de aengebragte goederen aengemoedicht werden, vertoonende sich als de har(t)ste parthij omme op sijn duursie die haar maar aen te smeeren. Ondertussen geeft hij aen sijn gunstelingen te kennen tot wat prijs dat de waaren dienen afgestaan te werden, waarnae de snoodste ongemerckt weeten te neijgen om reedenen booven gesegt en dat sij in haar particuliere profijten niet souden besnoijt werden. Soodaanich gaat het met de meeste overhaalende stemmen door, terwijl den voorseijden maackelaar in de Moorse of Portugeesche taal met veel uijtwendige gebeerden tusschen beijde schijnt te gaan omme de nieuwelingen en onnoselen maar te blinthocken. Voorts om alles wel te besluuten tot haar meeste reputatie wert soodaenigen vercoop in Compagnie's resolutieboeck gestelt, en gesegt dat de voorseijde goederen etc. met eenpaarigheijt van stemmen en ten meesten voordeele van de Compagnie sijn aen de man gebragt etc. nevens veel meer opgeproncte plasdancken, twelck naar alle plaatsen tot in 't Vaaderlant toe op 't aldercierlijckst geadviseert wert, ' waardoor men noch tot de qualiteijt van Raadt extraordinaris van Indiën comt te geraacken! Strekt deesen Raadt van Ougly wel anders als tot een deckmantel van de heeren directeurs haar ontrouw? alsoo de conscientieuse altijt overstemt, aenstonts afgeset of versonden werden.

Hoe het in oude tijden pleeg te gaan. In voorige tijden vermogten de hoofden van de binnencomptoiren als daar sijn Cassimabassaar, Decca, Malda, Pattena, Bellasoor etc. van 't hooftcomptoir, ${ }^{2}$ daar de heeren directeurs leggen, sodaanige

$1 \mathrm{Di}$. in de brieven, tot in die an de Bewindhebbers in het Vaderland toe gemeld wordt.

1 Hougly. 
eijschen van coopmanschappen te doen als sij dagten in dat jaar met de meeste voordeelen van d'Edele Compagnie te sullen cunnen vertieren, daaruijt ontstont dat de hoogste marckt in den vercoop in 't openbaar wierde behaalt en een suunige aenbesteedinge geschiede van den incoop beeter overeencoomende met de meeninge der heeren Majores, schietende alsdan bij de boexkens aldaar moije winsten jaarlijx over. En als de packen afgecoomen waaren opende men eenige daarvan opt hooftcomptoir en naar bevindinge derselve wierden de versenders ofte hoofden van de binnencomptoiren aengemoedigt of streng gestraft, alsoo de heeren directeurs daarvan dan geen voordeel hebben conden.

Bewijs dat de voorseijde heijdenen geen rechtschaape cooplieden maar commissarissen van de directeurs sijn. Daar het nu alles in Ougly aen de voornoemde Sonderdas en Diepsienta als openbaare cooplieden aengeborgt ende door haar vervoert wert naer de voorseijde binnencomptoiren, daar het meerder rendement ordinaris van 20,25 en wel 30 procento ten profijte van den directeur alleen comt, uijt welken hoofde sij gemelte heijdenen wel tot 4 à 5 tonnen gouds derven borgen, daar men seeckerlijck weet dat sij ijder geen 15000 eijgen hebben. Voegt hierbij de slaafagtige onderwerpinge daarmeede sij haar voor den directeur des avonts en smergens coomen verneederen daar sij anders superbe ${ }^{1}$ van aart sijn, noch dat sij noijt contant coopen en dat den directeur aen niemant anders wil vercoopen, schoon andere cooplieden met contanten ter marckt quamen of dubbele verseeckeringe gaaven, gelijck wij een klaar exempel gesien hebben anno 1682 met schipper Jan Brengman, hoe schendigh hij getracteert wiert met de sijne als hij in den openbaaren Raad de chiancos ${ }^{2}$ tot 25 à 30 procento hooger ten profijte van d'Edele Compagnie hadde gecogt, en daarvoor sulcke verseeckerde borgen stelde alsof 't contant betaalt was. Hoe can 't mogelijck sijn dat sij, te weeten de voorgemelte cooplieden, in soo lange jaaren geen meerder capitaalen hebben te booven gelegt? Booven dit alles, dat men seecker weet, geeft dit waare preuven dat sij Sonderdas en Diepsienta onder de hant

\footnotetext{
1 Trotsch.

- Een soort van kinkhorens, door de Hindoes gebruikt voor het plengen van drankoffers, het maken van hoorngeschal in tempels, en het vervaardigen van armbanden en andere sieradiën.
} 
maar factoors van de directeurs sijn en gewaande cooplieden van d'Edele Compagnie. Want alles wat buuten deese heijdenen verhandeld wert, daar heeft den directeur geen voordeel van.

Van den incoop of aenbesteeding der goederen en coopmanschappen voor d'Edele Compagnie over de $l i j w a$ aten etc. In soodaniger voege gaat het meede met de aenbesteedinge van alle waaren die daar vallen, maar dat werd buuten den Raad gehandelt tusschen den directeur en de voornoemde Sonderdas, Diepsienta en Siawiswas als maackelaar. Ende om dat al meede een goeden glimp te geeven, neemt den directeur daar monsters van volgens het accord en druct er sijn zegel op, dat met 'et inleveren wel 8 à 10 procento van de merktsprijs in slegtigheijt of duurte comt te verscheelen, wanneer de voornoemde gunstelingen al weer te passe coomen int naesien en prisetren derselve. Daarna weet dien meergemelten fielt Siawiswas tussen den directeur en sijn voornoemte factoors die prijsen teegen de merckt soodaenich te balanceeren dat den heer (directeur) daar best af vaart, laatende voor haar Sonderdas en Diepsienta haar factorij ${ }^{1}$ overschieten. Ingevalle sij door sulck doen al niet tevreeden waaren en quamen verstooten te werden, dan stonden se seeckerlijck in armoede te vervallen omdat haar staat soo hoogh opgetrocken is dat, alse geen stut aen de Compagnie meer hadden, alle gewelden van de Mooren onderworpen soude weesen. Daarom blijven sij liever in des directeurs gewelt hoe qualijck het haar oock mogte gaan, dewijl er altijt noch voordeel bij valt.

Van den hennip. Den hennip, die tussen Ougly en Barnegoor de revier langs valt, wort door den maackelaar Siawiswas ingecogt en heeft daarvan sijn voordeelen nevens sijn maackelaerdije door den incoop, daar de naeuste prijs niet van aengedient wert, en 't vereffenen en sluuten van den coop en vercoop als booven is gesegt. Bij onse tijt cogt men den besten hennip op Polta voor 13 à 14 ane $^{2}$ de $68 \ll$ Hollants, dat de Compagnie tot 28 à 30 ane in reecqening comt te staan en door de cassier aen voornoemden maackelaar op ordonnantie van den directeur betaalt wert, gaande 16 ane in een ropij van 28 stuuver Hollants, twelck over een capitael ${ }^{3}$ verscheelt. Dan comt den ondercoop-

1 Hun factoors- of commissieloon.

- Een anna $=T^{1}$ ropï.

- Meer dan 100 procent. 
man en lijnbaanmeester noch die de parthije hennip ontfangt om daar touwen, lont etc. van te laaten slaan, die weet daar noch 2000 à 2500 ropia uijt te puuren meest comende uijt het sweet van den arbeijtsman, of dat se het beste weeten aen de vrijschippers ' te vercoopen. Van deese winsten derven se in den dronck noch roemen.

$\mathrm{Van}$ de rijst. Op deselve manier gaat het met den incoop van den rijst, die van Batavia voor gansch Indiën ontbooden wert, somtijts tot een quantiteijt van $16,17,18$ jaar wel 1900 lasten, ider last van $3000 \ll$, dewelcke almeede van den voorseijden maackelaar ingecogt wert, moetende bij onse tijt d'Edele Compagnie voor $2 \frac{1}{2}$ man, ijder van $68 \ll$, een ropij betaalen, daar seecker oud-ondercoopman den directeur Bauckes ${ }^{2}$ derfde aenwijsen, dat hij $3 \frac{1}{4}$ man voor een ropij van 28 stuuver conde becoomen, en dat noch veel beeter corl, daarbij d'Edele Compagmie ontrent 30 procento soude geprofijteert hebben. Maar dien trouwen dienaar, die 's vaaders voetstappen sogt na te volgen, wiert in den Raad altijt overstemt en was onrechtveerdelijck van 't fiscaal ampt afgeset, en eijndlijck anno 1682 met het Waapen van der Goes naar Batavia affronteuselijck versonden, sonder de alderminste reeden aen hem te geeven noch in 's Compagnie's brieven daarvan gewag te derven maacken. waarover de welmenende heeren tot Batavia komende niet weijnich spotteden. Wel magh den propheet Jasaias seggen Cap. 59 vers 15 , dat wie van het boose afwijckt sigh tot een roof stelt.

Fraudeleuse handeling door e en aparte kleijne opgeregte Compagnie door den directeurs huusvrouw. $\mathrm{Nu}$ moeten wij eens verder vertoonen de niewe practiq, die van ' $t$ jaar 1679 is begonnen en daarnae genougsaem publiq in Bengale heeft gecontinueert, van een bijsondere $\mathrm{kleij}$ ne Compagnie op te rigten met ongluucking van den heer directeur, twelck door sijn huusvrouw geschiede, die tot dien eijnde haar neef tot fiscaal en een ander pachuusmeester tot haar verseeckering in haar compagnie wist te krijgen. En om dit werck wel aen te leggen nam den fiscaal soo veel pions of inlantse soldaaten te land ende te waater aen in roeijschuijtjes van 6

1 De voor eigen rekening, niet in Compagnie's dienst, varende schippers.

2 Nicolars Bauckes, directeur van Bengalen van 1681-1683. 
riemen, als hem tot besettinge van alle de scheepen van d'Edele Compagnie die langst de rievier voor de logie en voor Barnegoor leggen noodigh dacht te weesen om al 't particulier (handelen) op het naust te weeren, op voorgeven dat den grootsten dienst van d'Edele Compagnie sulx vereijschte, tot welcke ongelden jaarlijx voor reecqening van d'Edele Compagnie $f 4000$ à $f 5000$ verspilt wert. Dit middel soude wel goet weesen als 't tot een goed eijnde voor d'Edele Compagnie gebruuckt wiert, maar naderhant als men wat verder uijt sijn oogen begon te sien, sagh men naackt en klaar dat alle deese scherpe toesigt bedrieglijck was en alleenlijck geschiede om al de enden, gelijck men segt, in haar fuuck of hock te jaagen, dat is om de scheepsvrienden als schippers, ondercooplieden, boechouders, opperstuurlieden, chirugijns en kranckbesoeckers van vermogen en die voor de grooten van Batavia waaren, haar particuliere goederen bij den pachuusmeester te doen coopen ofte anders rigoureus te doen aenslaan ende te confisqueeren. En opdat daarop niets te seggen soude vallen, dewijl ijder wel wat van de Indische stockvisvellen diende te hebben wert den pachuusmeester door den heer directeur behendich voorsien van de alderbeste, eerste en bestenkoops incoop van amphioen of opium uijt Pattena, rouwe zijde en armosijnen ${ }^{1}$ uijt Cassimabasaar etc. En als deese waaren op die plaatsen door een vreemde heijdense hant en naam ingecogt sijn dan geeft den directeur eerst absoluute ordre en last aen de hoofden van de binnencomptoiren om voor 's Compagnie's reecqening in te coopen, wanneer den amphioen van 85 en 90 tot 120 à 124 ropia de man van $72 \mathbb{B}$ gereesen is, gelijk wij anno 1680 en 1681 bijgewoont hebben. Als dit particulier (goet) dan afcomt wert het in een en deselfde paccagie en vaartuugen met 's Compagnie's goederen gedaan, soodat men uijterlijck niet anders kan sien of 't is alles voor d'Edele Compagnie. Deese coopmanschap in Ougly gecoomen weesende wert het door den voornoemden pachuusmeester in 's Compagnie's pachuusen gebergt, waaruijt hij het alneeven 's Compagnie's goederen tot binnenboort van d'Edele Compagnie's boodems weet te laaten bestuuwen, neemende op hem alle periculen die hij voorgeeft daarin te sijn geleegen, waarvoor hij wel 168 ropia de man van $68 \mathbb{R}$ Hollants weet te bedingen, dat met de andere waaren

1 Een soort van zijdeweefsels. 
soo naar proportie gaat. Deese overwinsten moogen door malckanderen wel op 58 procento gesteld werden. Door dit doen is deese vuule morsserije soo in treijn geraackt, dat sij in haar vertier de eijschen voor Batavia en Mallabaar van d'Edele Compagnie niet behoeven te wijcken. Men kan afmeeten daar een lacqueij door sijn schoesmeeren tot ondercoopman en pachuijsmeester raackende in $3 \frac{1}{2}$ à 4 jaren tijts 150.000 gulden voor sijn portie in 't Vaderlant brengt, en sijn patronesse, de voornoemde huusvrouw van den directeur, naderhant weduwe in Den Haach, 6 tonnen gouds. Wat naadeel d'Edele Compagnie daarmeede is geschiet, bijsonder als men daarenbooven aenmerckt dat de prijsen van den opium 300,350 en 400 rijxdaaldaars d' $125 \mathbb{R}$ tot Batavia in 't gemeen heeft gegolden, en bij groote schaarsheijt 800 ja wel 1200 rijxdaalders is vercoght. ' En vermits de Javanen buijten 't gebruijc van dien drop qualijck konnen leeven geeft dat sap, bij sulcke morsseriën $2 \frac{1}{2}$ à 3 centen ${ }^{2}$ winst. Wat soude het dan geeven als er de helft minder quam of dat. alles in 's Compagnie's handen sijnde, de markt bij haar alleen conde geset werden, en dat de Hooge Reegering tot Batavia met 'et aencoomen van de Bengaalsvaarders of ter gelegener tijt, als sij de hoogste prijs dagten te connen behaalen, bij beckengeslach hetselve lieten vercoopen in plaats dat men het in de pachuusen van 't Casteel laat verdroogen, als wij anno 1683 en 1684 gesien hebben, totdat al 't voorseijde particulier vertiert was naar te Oostcust van Java ende de rouwe sijde en armosijnen etc. naar Japan.

Van 'tverswijgen der thollen. Boven 't bedrog op de coopmanschappen en alderhande complotterijen comt het sluijcken der thollen voorbij haar derbaan of het rechthuus der Mooren, geevende den directeur de qualiteijt wel aen maar de quantiteijt

1 Van Dam vermeldt in zijn Besehrijvinge van de Compagnie (Boek III capittel 21) dat niettegenstaande de plakkaten der Hooge Regeering van 7 Juli 1667 en 31 Mei 1683 de particuliere handel „even groot en grof bleef continuëeren, voornamelijk tusschen Bengalen en Batavia, en dat vooral in den amfioen, een koopmanschap voor de Compagnie alleen gereserveerd, die de luiden op velerhande manieren wisten te verbergen en met groote en kleine pakjes over te voeren, waardoor Compagnie's eigen goed tot een instal werd gebracht (gedeprecieerd) en de markt teenemaal bedorven, zijnde notabel dat dezelve vóór dien tijd op haren aangebrschien en vertierden amfioen in één .jaar tusschen de zeven en acht tonnen hadde geprofiteerd."

D. i. procenten. 
verswijgende, weetende dat ontrent de thollenaars met de jaarlijxe groote geschencken voor reecqening van de Compagnie soo te stellen dat sulcx soo blijft heenslenteren. Ondertusschen comt het versweegene ten profijte van den directeur, en om het almeede een goeden schijn te geeven laaten sij bij de reecqening van de vertholde goederen in de boecken wat overschieten, en soo daarover met de Mooren enig misnoegen ontstaat of wel om meerder oorsaacken openbaare geschillen rijsen, dewijl sij niet heel geck sijn, dan weeten de heeren directeurs haar brieven naar 't Patria en Batavia tot haar verschooning soodaanich op te proncken alsof sij het grootste gelijck van de weerelt hadden. Van deese post is in voorige tijden veel ommeslagh gemaackt, daarom sullen wij daer van affscheijden, niet twijfelende of de heer Isaack Soolmans ${ }^{1}$ ende sijn hoogedele de heer Henderick van Rhede ${ }^{2}$ sullen dit claarder aen den dach brengen.

Van de incomsten van 's Compagnie's vergunde jurisdictie. D' incomsten van 's Compagnie's gebiet, haar van outs vergunt over de merckt voor de logie van Ougly mitsgaders daaragter over de dorpen van Cinçura en Barnegoor meriteeren aengeroert te werden. Deese plaatsen sijn seedert eenige jaaren in neering en volckrijcheijt soo toegenoomen dat 'et te verwonderen is, willende de inlanders gelockt door de smaack van de vrijheijt onder ons liever coomen woonen als onder de wrevelige en geltsugtige Mooren. Hiervan wert geen post in de boecken gevonden. Den directeur laat door Siawiswas van huus tot huusje soodaanige schattinge invorderen als die Bengaalders ider naar advenant 's Mogols lant beslaan, en daarin wort naar 't oud gebruuck betaalt doe er bijna geen menschen woonden. 't Overige gaat almeede naar den heer directeurs beurs.

Alle periculen en oncosten werden de Compagnie op den hals geschooven en de winsten in haarsack. In somma: 't onderhouden van son veel Europeesche en inlans dienaaren op de binnencomptoiren, ' $t$ bouwen en repareeren van die logies en veel meer andere ongelden werden nu als een last van d'Edele Compagnie gebouckt, omdat den directeur alles

1 Isaac Soolmans, visitateur-generaal te Batavia, werd in 1684 toegeroegd aan Van Rheede van Drakesteijn in diens zending als Commissaris-Generaal naar Coromandel enz.

? Hendrik van Rheede van Drakesteijn, Commissaris-Generaal in Coromandel, enz. $(1684-1691)$. 
in Ougly de gemelte heijdenen laat doen, waardoor hij het meerder rendement op de binneplaatsen door het vervoeren en vercoopen van de voornoemde heijdenen en den duuren incoop of aenbesteeding van de goederen self aen hem weet te trecken sonder een stuuver perikel te loopen, want alles wat die maats wert aengeborgt en dat haar mogte overcoomen loopt op risico van d'E. Compagnie alsoo sij als suffiçante cooplieden voor alles aen de Compagnie gedebiteert staan.

$\mathrm{Remedie.} \mathrm{Om} \mathrm{dit} \mathrm{voorige} \mathrm{soo} \mathrm{veel} \mathrm{doenlijck} \mathrm{te} \mathrm{verbeeteren}$ dunckt ons dat den heer directeur buuten den Ouglyschen Raadt niets behoorde te doen, noch dat hij niemant van de Raadspersoonen aén ofte af mogte setten veel min te versenden, maar dat sijlieden neevens den fiscaal van de Hooge Regeeringe tot Batavia alleen moeste dependeren, en dat ijders advijs in den Raad in 't resolutieboeck aengeteeckent sijnde door haar Edelens beeter reflectie soude connen genoomen werden op en tot het avancement van de trouwe dienaaren, dewelke daardoor te meer souden werden aengemoedigt om vrijmoediger ten dienste van d'Edele Compagnie in den Raad te derven spreecken. Verders weegen 't sluijcken der tollen ende de incomsten van 's Compagnie's gebiet: van 't laetste moet nootsaackelijck een post in de boucken gehouden werder, aengaende 't eerste soude door twee gecommetteerden uijt den Raadt, die best ervaaren sijn in de Moorsche taal, buuten weeten van den Moorsen gouverneur deselve cunnen opgenoomen en bij notitie in de vergaadering van Ougly overgelevert werden. Indien alsdan bevonden wiert aan ' $t$ tholhuus wat meerder aengegeven en betaalt te sijn soude sulx, mits dat de Compagnie van de jaarlijxe excessive schencagies ontheft wierde, connen geleeden werden, twelck veel gerustheijt en voordeel geeven soude.

't Cargeeren van de oncost- of guastoshouders. De toelaatinge van de heeren directeurs dat de guastos- of oncosthouders van de Ouglyse logie soodaanich op alle haare leveringen, bijsonder aen de scheepen mogen cargeeren, ' is sijn opmerckingh waardigh. Den Benjaan ${ }^{2}$ Idemelck, die voor alle quade schulden instaat en alles wat tot die bedieninge van

I D. i. tot hoogeren prijs in de boeken stellen dan in werkelijkheid is betaald.

2 Hindoesch koopman, vooral uit Goezeratte, zie Hobson.Jobson i. v. banyan. 
nooden is besorgt, bood anno 167610.000 ropia of $f 14.000$ 's jaars te willen geeven mits dat denselven oncosthouder de maandelijxe reeckening naar gewoonte aen den directeur overleeveren en voorts stil sitten soude maer A. C. ${ }^{1}$ sloech dit plat af, en men bevont naar sijn overlijden dat er jaarlijx vrij meer overgeschooten had. Of den directeur van sulcke persoonen meede niet begroet en beschoncken wert heeft sijn bedencken, ten waare het neven van hem of van den Generaal ${ }^{2}$ sijn.

Remedie. Om deese groote schaade door gansch India daar scheepen aencoomen en verversing moeten genieten meede voor te coomen, soude 't naar ons overleg best sijn dat alle de gesaghebberen, kleen en groot, een ordonnantie gaaven aen de schippers en bouchouders van de scheepen om door den cassier aen haar betaalt te werden naar advenant sij volck ophebben, sooals sulx geschiet met reedelijcke ordre en op een prijslijcke manier op Batavia; dan souden die twee hoofden aen den bootsman, schieman, constapel, bottelier, cocq en alle de matroosen soo veel behandigen als ijder toecomt, dan weeten sij dat soo te overleggen dat die arme menschen wel rijckelijck eens soo veel deeg en voetsel er af hebben en daarmeede soo wel tevreede sijn dat men er plaisier aen siet, daar nu ter contrarij 't schelden en vloecken op den guastoshouder of leverancier over sijn godloose, magere, slegte leverantie van 't alderslegste goet, tot de alderduurste prijs de Compagnie in reecqening gebragt, steeds in swang gaat.

Over het laaden van de s.cheepen. Om de scheepsruijmen vol te laaden wert in 't lant door de heeren gesaghebberen weijnig sorg gedragen. De schippers uijt Bengale, Zouratte. Arracan etc. comende, daar den taruw en rijst ongemeen goeden coop is, laaden haar scheepen in 't gemeen geen $\frac{2}{3}$ voor d'Edele C'ompagnie en ruijm $\frac{1}{3}$ voor haar selven, wetende op ' $t$ een of 't ander pretext den directeur wat wijs te maacken, die het met oogluucking veeltijts laat passeeren omdat haar huusvrouwen die schippers met vele commissiën belasten voor de (ver)mogenste van Batavia en anderen.

Remedie. Tot voorcoominge van dit voorseijde importante point is niet wel iets anders te bedencken als dat alhier in 't

$1 \mathrm{Mij}$ onbekend.

D. i. Gou verneur-Generaal. 
Patria, wanneer de scheepen gemaact sijn, in handen van schippers en stuurlieden behoorden overgegeven te werden ende te blijven behoorlijcke charters van derselver laading, uijt dewelcke de gesaghebbers altijt bij calculatie souden connen sien wat en hoeveel goederen die boodems soude connen inneemen, en oock hier te lande daaruijt altijt connen naegespeurt werden of de Compagnie 's kielen behoorlijck op de reijsen in Indiën vollaaden wierden. Soude oock alle scheepen connen geordonneert werden gelaaden te moeten werden in 't bijsijn van den fiscaal en twee gecommitteerdens, die daarvan verclaaringe souden konnen geeven dat sij daar praesent waaren geweest totdat de luucken geslooten waaren etc.

Hoedanich alle particuliere goederen in en uijt Batavia coomen. Alle particuliere goederen van de vermogenste tot Batavia werden door de oppercooplieden nevens 's Compagnie's waaren in een en deselve packagie, als gesegt, in 's Compagnie's pachuusen in 't Casteel geborgen en voorts aen de Chineese cooplieden vercogt en daarneevens gelevert, d'andere mindere particulieren weeten, met corrumpering ' van de fiscaals, geweldige caffers ${ }^{2}$ en boomwagters, ${ }^{3}$ ja selfs tot de hartaderlijcke waaren als nagelen, nooten, opium etc. tot binnen Batavia te krijgen, jaa de laatste opsienders derven 't noch wel self coopen, gelijck anno 1682 als 't schip Helvoetsluus uijt Amboina quam is 't geschiet dat door de quartiermeesters Gillis en Dammes, beijde van Rotterdam met deselve boodem uijtgevaaren, met haer boot bij nagt hebben gebragt aen een inlands vaartuugh, vobr aen de mont van de rivier leggende, een groote parthij moernagelen om op ordre van de voorseijde boomwagters afgehaalt te worden.

Verval van gansch Indiën tsedert 1680 tot 1684. ' $t$ Was onder de regeering van den overleeden heer Generaal Speelman, ${ }^{4}$ door sijn schandelijcke begeerlijcheeden van ongehoorde schenckagies als anders te genieten en daardoor sijn gunstelingen op alle plaatzen voor gesaghebbers af te schicken, soo verre gecoomen dat, gelijck men seijt, alle seijlen tot de caperije blanck stonden, waardoor sij haar eed, eer en pligt

1 Omkooperij.

- Inlandsche gerechtsdienders.

- Tollenaars aan den tolboom in de rivier van Batavia.

- Cornelis Speelman, Gouverneur.Generaal van 1681 tot 1684. 
hadden vergeeten, en derfden sulcke geavanceerden onder andere discourssen wel seggen sij seecker wisten, dat de Engelse directeurs wel 15 en meer procento genooten van haar meesters goederen, die sij aldaar vernegotiëerden, en waarom dat haar sulx niet meede soude toecoomen? Die daarteegen soude hebben (willen) spreecken soude crimen laesae majestatis begaan hebben. 't Is een slecht recht en onnosele pretensie uijtgevonden, daar echter 'er al veel menschen in India meede flatteeren, te weeten dat de Compagnie voor 48 stuuver aen degeene diet gelt versoucken 64 stuuver op haar reecqening stelt: ${ }^{1}$ wel is waar dat het wat veel is maar de Compagnie behoeft oock voor niet haar gelt soo verre niet te laaten voeren. Het andere woort is: wie kan er van sijn gage en costgelt leeven? Dat moet men niet seggen ir Bengale, Zouratte, Chormandel, Ceijlon, Mallabaar etc.; selver om de Oost, ${ }^{2}$ als sij maar den stercken dranck niet en beminnen, kan men 't noch al ter nauwer noot ront schieten. Voorts nemen se het gebit op de tanden en seggen dat alle den omslach van d'Edele Compagnie doch voor de Jooden van Amsterdam is, ${ }^{3}$ overslaande om haar conscientie te streelen soo veel bedroefde, eerlijcke weduwen en weesen, die daarvan moeten leeven en soo meenige vroome, godvrugtige ledemaaten en patriotten, die haar middelen in 't eerst met weijnich hoope gewaacht en naar soo veel periculen noch in veele jaaren van oorloge niet hebben genooten, en wie weet of den Almagtigen om sulcke geallegueerde vromen d'Edele Compagnie niet noch en bewaart en tot dusverre gezegent heeft. Dese luijden sijn veeltijts van een geringen staat en aen de borsten van d'Edele Compagnie groot gemaackt, niet eens denckende dat er booven 't goet onthaal van gagie en costgelt met 'er tijt, soo sij maar patientie hebben, tegen den ouden dagh buuten 's Compagnie's schaade wel wat kan opgelegt werden door de stercke vaart van de particuliere Engelschen, Portugeesen en Mooren naar Persiën, Siam, Arracan, Actchijn, Tannasseriën, Maldives etc. oock wel binnenslands op veelderhande maniesen, waaronder gereeckent is dat men gelt op interest can uijtsetten tegens $1 \frac{1}{4}$ a $1 \frac{1}{2}$ procent 's maants, hoewel dit bij den articulbrief niet toegestaan wert om de quade gevolgen, soo sullen wij echter seggen dat alle

1 Vgl. mïn aangehaald opstel over de matrozen en soldaten, blz. 343 .

- De landen ten oosten van Java inzonderheid de Molukken.

s Vgl. hiervóór blz. 376 noot 1 .

D1. 76. 
Asiatise jaa self onse Europeese natie 't voorenstaande voor billick sullen oordeelen te moogen doen.

Aenmerckinge van de Engelsen en hoe't met ons soude cunnen gemodereert werden om de dienaren een weijnich licentie te geeven buuten schade van d'Edele Compagnie. D'Engelsen hebben voor een manier dat de hoogste officieren ijder naar haar qualiteijt buuten jaa self binnen de ruumen van haar scheepen eenige weijnige lasten werden toegestaan meede te moogen neemen en op haar arrivement publicq te vercoopen. Maar bij ons kan 't soo niet geschieden om den swaaren ommeslach van groote garnisoenen die wij t' onderhouden hebben en dat onse dienaaren door den banck wat meerder gagie genieten, of 't moste met bijsondere afsondering en buuten de volgende goederen sijn daar 's Compagnie's meeste welvaaren in bestaat, en dan noch buuten de ruumen soo veel sij in haar kisten cunnen bergen, als: giroffelnagelen, nootenmuscaad, fouelie, canneel, peper, amphioen, rouwe sijde, salpeter, cooper, vermeljoen, spiaulter, ${ }^{1}$ thin, loot en alderhande mineraal daar de Compagnie in handelt, indigo, arreeck, ${ }^{2}$ chiancos, borax, barnsteen, bloet- en tackcoraal, muscus, amber de grijs, quicsilver, camphur, armosinen, pelangs ${ }^{3}$, pansjies ${ }^{4}$, gilams ${ }^{5}$, phatholen ${ }^{6}$, alderhande rieckent hout, laackens, perpetuaanen ${ }^{7}$, guinees lijwaaten etc. En opdat daarin niet het alderminste soude werden geconniveert behoorden de twee fiscaals op Batavia leggende, daar 't alles genougsaam aen hangt, van de Edele Heeren Majores gestelt te werden, lieden van capaciteijt in regten en voorsien met een goede, bondige instructie, daarop sij alle jaaren eerst alhier en daarnaa op Batavia voor de Hooge Regeering haar eed in behoorlijcke forma afleggen souden, gelijck verder de fiscaals van de buutencomptoiren door deselve regeering aengestelt meede op deselve instructie mosten doen. Wij kunnen dan niet sien of 't soude tot redres van de vervallende saacken veel helpen, bijsonder

1 Een alliage van zink, koper en nikkel.

2 De noten van den arekapalm.

s Een soort van chitsen?

- Een mij onbekende stof.

- Een mij onbekendo stof.

- Een soort van zijdestoffen.

7 Een soort van wollen stoffen. 
als sij op haer aenclagte voorgestaan en wat meer gerespecteert wierden. Nu werden se niet geacht, en teegen dat 'et overgeschreeven is en bescheijt op verwacht wert is 't ordinaris al doot gebloet. Ondertussen stellen sij anderen daarmeede sij connen doen wat sij begeeren, ja schoon de particuliere goederen en coopmanschappen al aengeslaagen sijn derft den directeur die wederom ontslaan en weet die wel behendigh weg te laaten brengen, gelijck anno 1678 in Ougly is geschiet door W. V...' aen den fiscaal Sonnius, die een groot inlands vaartuug met sijdepacken van Cassumabassaar comende voor reecqening van den assistent Cornelis Chasteleijn ${ }^{2}$ aengehouden had, onder de hant ontslaagen is en daarnaer sonder de alderminste reeden, gelijck noch beweesen can werden, afgeset wordende noch alle smaat besuuren moste, daarvan in den incoop van de rijst hierbooven is gewach gemaackt. Daarom seggen wij nochmaalen dat he.t van een unbegrijpelijck quaden gevolge is, dat de fiscaals en Raadspersonen door de gesaghebberen af- en aengestelt cunnen werden, waardoor sij tot flicfloijers en ontrouwe oogendienaars moeten vervallen om $t$ ' avont of mergen bij 't eerste voorval tot een hooger en profijtabelder bediening te geraacken en dat haar gecargeerde maandelijcke reecqeningen niet moogen besnoeijt werden, blijvende soodoende als gesegt tot een decmantel van alle ontrouw die de heeren directeurs maar gelieven te bedrijven.

Remedie. Niet weijnich soude daartoe helpen dat de Hooge Regeering tot Batavia door een cleijn suuverinckje van diegeene, die 't reght door schenckagie buugen, soodaenige patriotten en liefhebbers van 's Compagnie's welstant daar geplaatst wierden, die van herten genegen waaren den $\sin$ en volcome meninge van haare heeren principalen te doen en helpen uijtvoeren, wanneer de heeren majores met soo veel ordres te geeven en anderen ommeslach van schrijven meer soo veel niet te doen souden hebben en bekommert sijn. Dan soude het verre genouch gebragt sijn aengesien sij overal soo naebij sijn en alle gebreecken aenstonts konnen doen verbeteren ten dienste van 't gemeen.

\footnotetext{
1 Klaarblijkelijk heeft de schrijver op het oog den directeur van Bengalen Willem Volger (1677-1678).

- Chastelein ging in 1675 als boekbouder naar Batavia, werd in 1682 ngroot winkelier", 1691 opperkoopman des Kasteels aldaar, later Raad-extraordinaris van Indië en overleed in 1714, hij stichtte de bekende Christengomeente te Depok.
} 
Oock connen sij onfeijlbaar met het aencoomen van alle scheepen seeckere preuven neemen of de waagen overal recht gaat of niet, daartoe ontbreekt er noijt stoffe door de menichvuldige begunstigde officieren, die jaarlijx over en weer vaaren en 't geen self niet noodich is tot een plasdanck nevens 't vernegotieerde weeten aen te dienen om op de naeste reijs op een goede profijtabele tocht wederom te geraacken, maar de Batavise heeren bedienen sich daarvan stilswijgende sonder eenich gewach in de vergadering ten dienste van d'Edele Compagnie daarvan te maacken. In soodaniger voegen (onder verbetering) was ' $t$ alhier ten naesten bij meede te doen door het ondersoecken van d'E. Heeren Majores aen de eerlijcke overgecomene oude dienaaren hoe het door geheel India tot Batavia toe incluijs al gaet, twelck niet geweijgert soude werden als 't tusschen vier oogen geschiede om de moeijelijckheijt voor te coomen, dewijl s' er geen voordeel van konnen. hebben.

Over de verantwoording van de laading, victualie en equipagegoederen. Oock sal 't de Compagnie veel profijteeren wanneer de schippers $\frac{1}{2}$, de boechouders $\frac{1}{4}$ en de opperstuurlieden ' $t$ resterende $\frac{1}{4}$, soo binnenslants en van hier vaarende, in de te cort coomende laading, victualie en equipagegoederen quamen te draagen, omdat de stuurlieden over 't ruijm gaan en den boechouder haast noijt daarin comt, in plaets dat nu den schipper en boechouder ider $\frac{1}{2}$ moeten verantwoorden. Daaruijt soude dan ontstaen dat den opperstuurman sigh bij den boechouder soude voegen omme gesamentlijck te helpen sorgen, dat de schippers haar personagie bijsonder over de victalie en equipagegoederen soo veel niet souden connen speelen ' en de niewe onkundige boechouders abuseeren met de volgende practijken, als dat sij voor de eerste of tweede maant van hier in see sijnde geloopen geen volcoomen rantsoen geeven na de ordre van d'Edele Compagnie; ${ }^{1}$ ten tweeden dat sij seggen veel meer extraordinaris rantsoen in storm, nat, vuul en hart weer aen de matrosen en siecken gegeven te hebben als ' $t$ in der daat is; ten derden dat er veel vaaten wan ${ }^{3}$ en groote

1 Vgl. over de malversatiën door baatzuchtige scheepsbevelhebbers op dit stak gepleegd mijn opstel "De voeding op de schepen der Oost-Indische Compagnie" in deze Bïdragen Dl. 67 blz. 543 vlg.

- De grootte der te verstrekken rantsoenen was bij de zoogenaamde rantsoenlijsten uitdrukkelijk vastgesteld.

s Lek. 
leccagie in gevonden is; ten vierden weet men de maat van dranck met de vinger of duijm daarin te houden niet vol over te geeven, en veel meer sulcke behulpmiddelen van ongerechtigheden die hier te lang sijn om te verhaalen, twelck door practijcq van den bottelier op ordre van den schipper uijtgevoert wert, die alle Saturdagen na d'ordre van de Compagnie de reecqening moet opmaacken en aen den schipper overgeeft, en die behandigt het aen den boechouder dewelcke het onnoselijck en ter goeder trouw in 't consumptieboeck stelt. 't Selve can van de equipagegoederen door den bootsman, schieman en constapel meede gedaan worden. Door sulck doen comt op een lange reijs veel over te schieten, sonder weeten van den boeckhouder maar niet van den stuurman, die veeltijts daar bij staat om goede ordre te houden: Wanneer de provisie en equipagegoederen soodanich in 't ruijm versamelt sijn dan weeten de ontrouwe schippers, als sij op Batavia's rede gecoomen sijn, aen de vrijluijden, dat tappers, waerden of sulcke vuulicken sijn, de provisie en aen vrijschippers van inlantse en andere vaartuugen de equipagegoederen te vercoopen en bij nacht of ontijde door den bottelier de coxpoort te doen uijtsteecken. Hoe kan dan den boechouder, die veeltijts aen lant is en als hij scheep is in de cajuijt slaapt, daarvan weeten? Daarenbooven hangt het gansche scheepsvolck aen den schipper ${ }^{1}$ soodat den boechouder de chaloup van 't schip niet kan krijgen al was 't tot 's Compagnie's dienst of moet den schipper beleeft daarom versoucken, en die staat het met een goede buij toe evenals iemant aen een ander sijn eijgen beste paart leent. Soo d'er nu al vroome schippers sijn, die behouden het overschot van de provisie etc. in haar schip en deelen 't op sijn tijt aen de gemeente omdat sij in India soo rijcklijck van de patriase provisie niet voorsien worden. Door sulck gedoente blijven de magasijnen op Batavia soo weijnich voorsien.

Remedie. Om het vercoopen en uijtsetten van de voorseijde goederen ${ }^{2}$ uijt de koxpoort soo veel doenlijck te remedieeren dunct ons dit dienstig te sullen sijn: op het inseijlen van de Straat Sunda krijgt sijn Edele daarvan aanstonts kennis, waarop den geweldigen dan volgt, en als 't schip sijn ancker op Batavia's

1 Hangt geheel van den sohipper af.

- De voor rekening van particulioren asngebrachto goederen. 
rheede heeft laaten vallen, dan volgt den fiscaal, alsdan behoorde den visitateur nevens twee bequame gecommitteerdens daarop te volgen, die in de caamers, ruijmen etc. gingen, en wanneer sij met malckanderen alles gepeijlt en opgeschreeven hadden tselve onder presentatie van eede aen den heer directeur-generaal ${ }^{1}$ over te leveren, welcke beëedigde bevindinge door den visitateurgeneraal ${ }^{2}$ tegens des boekhouders consumptieboexkens dan moest naargesien werden. Ten waare dan den ganschen hoop malckanderen niet verstaat moet het vogeltje op het nestje gevat werden.

Van 't verschansen ${ }^{3}$ der schippers op Batavia's rede. 't Is voor de Compagnie meede groote schaade dat de schippers, als sij met haar scheepen die sij van haar principaalen becoomen hebben op Batavia coomen; veeltijts daar van geset of geordonneert worden op een anderen boodem over te gaan, waardoor onlust en tegensin ontstaat, en veroorsaackt dat de timmerluijden die groote huuren winnen naar behooren niet belast werden deselve te voorsien nae de vereijste sinnelijckheijt van dat gebeuijtel, * segge seevolck, waardoor die kostelijcke bodems veel eer moeten afgeleijt ${ }^{5}$ werden als den behoorlijcken tijt daarvan meedebrengt, tot een onbegrijpelijcke schade, gereeckent over de geheele massa, voor de Compagnie. Oock worden de scheepen door dat verschansen soo schandelijck ontbloot alsof se eerst van de werf waaren afgeloopen. Hiervan cunnen wij geen andere reeden uijtvorschen als dat een ijder, die daarin 't meest te seggen heeft, elck de sijne van de schippers op de meest winstgevende togten soeckt te helpen, en soo de schippers op alle vaarten niet bedreeven sijn ontbreeken d'er noijt lootzen of stuurluijden om haar overal in India te brengen. Maar in tijde van oorloge siet men nae de persoonen wie daartoe ' $t$ bequaamste geoordeelt wert.

Remedie. Verre soude dan het beste sijn dat ijder schipper

1 De directeur-generaal te Batavia was belast met het onmiddellijk beleid van Compagaie's handel, hield het toezicht op hare schepen en pakhuizen en bewaarde de sleutels van deze laatste onder zich.

- De visitateur-generaal te Batavia bad tot taak het controleeren van de handelsboeken, zoowel die van Batavia zelf als die der buiten comptoiren, alsmede van die welke op de schepen waren gehouden, en was verplicht van zijn bevindingen rapport te doen an den directeur-generaal.

3 Verplaatsen, verchangeeren.

4 Vgl. buitelaar, een spotnaam in zeemanstaal voor matroos.

3 Buiten dienst gesteld. 
op sijn uijtgebragte schip soude blijven continuëeren totdat hij thuus wilde vaaren, en dat hij in die tijt door sijn sinnelijckheijt en lust tot sijn houten huus of paart door de timmerluijden er soodanich de hant aen mogt laaten houden, dat de Compagnie veel meerder jaaren haar gebruijck en dienst daarvan mogte genieten.

Geen persoon voor commissaris en directeur gelijckelijck te senden. Dat een persoon van Batavia gesonden wert naa een buutenplaats voor commissaris en directeur gelijckelijck dunct ons oneijgentlijck te sijn. Echter is het seedert corte jaaren soo nae Bengale ' als Souratte geschiet. Den commissaris moet den directeur in sijn faulten soecken t'agterhaalen, daar men integendeel aen alle in onsen tijt gesien heeft dat sij het commissarischap soo ras van den hals werpen als sij 't met fatzoen doen konnen, om maar aen den smaackelijcken ontbijt van 't directeurschap te geraacken, waarin sij (onder reverentie) de honden slagten die tot haar uijtbraacsel weederkeeren.

Van de vrijluijden en rijcke Compagniesdienarenweduwen. Weegens de rijcke vrijluijden en 's Compagnie's dienaars weduwen vinden wij ons verschuldigt iets te seggen, als dat wij niet connen sien wat voordeel de Compagnie daarvan heeft, aengesien Batavia door ' $t$ garnisoen alleen bewaart moet werden en sijluijden daartoe gans geen last en dragen gelijck wij hier te lande doen, want verpondingen, $200^{\text {ste }}$ penning tsij reëel of personeel of sulcke diergelijcke schattingen meer sijn daar niet bekent, daar sij op Batavia eens soo veel interrest bij de Compagnie van haar capitaalen trecken, die veeltijts door haar voorseijde mans op de voorverhaalde manieren sijn vergaadert, maar ter contrarie sien wij dat se stil sitten, verlangen en hunckeren naar het aenleggen en wegsenden der scheepen van d'Edele Compagnie, die op de meest winstgeevende plaatzen gaan, om aen de onvermogenste vaarende dienaaren, als schippers, ondercoopluijden, boechouders, assistenten, stuurluijden, chirugijns, cranckbesoeckers en mindere officieren, haare penningen op halve winst of bodemerie ${ }^{2}$ te geeven tegen de volgende prijsen: als naar Bengaale 25 à 30 , Zouratte en Persiën

\footnotetext{
1 Wat Bengalen betreft was dit geschied met Willem Volger in 1672 en Nicolaas Baukes in 1683.

- Voorsohieten, leenen van kapitaal onder verband van schip of lading of wel van beide.
} 
20 à 25 en soo vervolgens, tot deselve cours na de Cust Chormandel, China etc., de minder winstgevende comptoiren pro rato, alles naa de goederen op Batavia coomen te rendeeren weten se de naaste reijs te reeckenen en verscheijde cleijne commissijtjes toe te bedingen, dat voor haarluijden noch een buutencansje is.

't Senden uijt Patria van de hooge gequalificeerde ' persoonen. Voor 't laest moeten wij, onder verbetering, noch seggen dat de Compagnie groot interrest comt te lijden met het senden van groote gequalificeerde niewelingen, daarvan gans geen preuven sijn van bequaamheeden ${ }^{2}$ noch trouwheijt, en die

1 De ambtenaren van hoogeren rang.

- Vgl. hierbij de volgende opmerkingen in de ${ }_{n}$ Aanmerkingen over den jegen woordigen toestand der zaken van de Generale Nederlandsche geoctroijeerde Oost-Indische Compagnie in Indiën (circa 1750) $n$.... consequentelijk is 't allenzints indisputabel en uijt de menig vuldige experiëntiën ten vollen evident even datgene mij bij deze gelegentheid herinnere eens (alhier van applicatie) gelezen te hebben in een briefjen, door zekeren dienaar in Oost-Indiën geschreven aan een zijner vrienden in Nederland, alwaar hij onder meer andre redenen zich ten dezen zeer opmerklijk expliceert als hij op deze wijze in alle vrijmoedigheid zegt: onderkooplieden komen uijt het Vaderland medebrengende vijfvoetskisten vol recommandatiebrieven, zijn gaillarde jonkertjes die wel in vermaak en allerbande galante divertissementen volleert zijn maar geenzints van eenen moeijlijken of de herzens fatiguëerenden arbeid weten, ja fluctueren nog hierteboven in die detestable en alles destruërende maximes dat het beneden het caracter vān hunne geboorte zoude strijden de handen aan de ploeg te slaan, en zich te appliceren om eenige wezentlïke experiëntiën van zaken te bekomen het wezentlijke interest van de gemelde Compagnie concerrerende. En nietjegenstaande dat alles (zegt hij verder) dicteert de politicque reden dat ze geholpen moeten werden gefavoriseerd wezende. Hunne beurzen op eeu behendige doch teffens indirecte (wijze) wel gevuld hebbende gaan zij, zoo wijs als zij nopens bet wezentlijke interieur der zaken gecomen zijn, welgespect weder oploeven werwaart zij maar weinige jaren bevorens zeer sober en mager van daan gekomen zijn. Ondertusschen (zegt deze schrijver en mogelijk uijt eigen experiëntie) worden wij gebruikt voor Christoffels om zulke luije en onkundige hanzen door de diepe wateren van hunne gedeman. deerde bezigheden heen te dragen zonder eens bedanktje te mogen hebben, en onze algemeene belooninge is op 't einde egaal met de oude afgeleefde jagerspaarden in Nederland, dewelke uit vreeze van aan den dijk gejaagd te worden van zelve sterven." - Dat hier de vinger wordt gelegd op oud zeer, toont de volgende plaats uit Van Dam's Beschrijvinge van de Compagnie (Boek I Deel I cap 18) „men beschuldigt doorgaans die van Indië over de non-observantie van de ordres, die haar van hier worden toegezonden en aanbevolen, en recommandeert haar niet als personen van bekwaambeid voort te zetten volgens den eed dien zij hebben gedaan, maar zij, ziende dat men hier zelf contrarie doet van hetgene men van haar wil gedaan hebben, zijn 
maar enckelijck uijt gunst uijt het Vaderlant gesonden werden, gelijck anno 1685 er een tot Amsterdam aengenoomen sijnde uijt Texel is geseijlt met een swaare familie en 50 pijpen ${ }^{1}$ Carelstats en Bronswijx bier, die voedervaaten ${ }^{2}$ en twee toelasten ${ }^{3}$ Rijnsche wijn nevens veel brandewijnen en gedistilleerde wateren, kisten en kasten met alderhande niewemodese stoffen, bedragende een somme van 20.000 gulden ongevaar, dewelcke door sijn swagers hulp, die een groot rijck coopman is, alle die goederen eerst heeft weeten te crijgen in 't schip van schipper Michiel Colombo die in Texel seijlreede lach na Sarante, en soo voorts weeder de voorseijde goederen heeft weeten over te crijgen bij nacht en ontijde in 't Oost-Indische schip 't Land Schouwen, dat daar meede met den voornoemden Raad extra-ordinaris klaar lach. Dit geallegueerde soude noch wel het minste sijn, maar de persoon selfs nevens sulcken swaare familie en bloetvrienden die met hem over sijn gegaan, moeten alle met swaare costen van de Compagnie opgequeeckt en groot gemaakt werden totdat sij aldaar meede met soodaanige gunst geholpen sijn. Wat dit cost en schadelijck is en is niet wel met gedagten te doorgronden, en sullen om cort te sijn daar maar alleen van seggen dat de ervarentheijt genouch leert, dat jde soodanigen sich bij en naar andere heeren van de Hooge Regeering voegen die geen last van vrienden hebben, alles in den Raad toegevende omme haar kinderen, heele en halve broeders maar op alderhande manieren te doen voorthelpen. Wat staat van desulcke te hoopen als alles weg te schraapen waar sij maar bedectelijck kunnen

die bevelen van dat respect noch die kracht niet gelijk wel zoude vereischen of behooren te wezen. En dit is mede onder andere de oorzaak dat men doorgaans in Indië heeft en aanhoudt zooveel onbekwame en gedebaucheerde personen, want de zoodanige betzij underkouplieden of adsistenten, men verzwijgt nog die in hooger bedieninge van hier gaan, brengen doorgaans mede brieven van adres en recommandatie, dewelke bij die van Indië moeten worden gerespecteerd hoewel de ordres contrarie liggen, zijnde verscheidene exempelen dat de zoodanige herwaarts opgezonden wezende weinig daarna weder in hooger qualiteit in Indië zijn gekomen. Wie zal dan zoodanige ordres van dezelve op te zenden durven nakoneu, vreezeude daardoor mede te zullen incurreeren en op den hals halen de indignatie van diegenen, die haar patronen hier te laude zijn?"

1 Lang pïpvormig vat.

Groot wijnvat.

Als voren.

4 Sorrento. 
bij coomen, gelijck den geseijden Raad extra-ordinaris bij verscheijde Indiesvaarders sich in tijts socht te informeeren, blijvende ondertussen treffelijcke, ervaarne, oude trouwe dienaaren alhier en in India lange jaaren verdruckt in eene bediening sitten, die tot menagie ${ }^{1}$ van de Compagnie wel twee of drie diensten souden connen waarneemen daar in Bengale, Chormandel, Souratte etc. één mans werck wel tot twee of drie gesplitst is om den overvloet van de pennisten ${ }^{2}$ maar te emploijeeren en werck te geeven. Soodanigh voorsiet men de scheepen oock al die op goede togten gaan in plaats van één somtijts drie om de overvloedige gunstelingen maar plaats te geeven en voort te helpen. Met reght moogen wij daarom seggen dat den overvloet van de dienaaren een cancker (voor) 's Compagnie's beurs is, want een ijder schoon hij vroom is soeckt sijn huusgesin met eere voor te staan op de beste manier, en die anders sijn scheelt 'et niet hoe sij er aen coomen gelijck wij overal hebben bevonden. Hoe swaarder parentages hoe grooter ballen over en weeder gekaatst werden, en of men malkander hier anders wil wijs maacken soo seggen wij nogmaalen dat den overvloet van de dienaaren een bederf van de Compagnie sal sijn, want daardoor coomen de winsten van de Compagnie soo besnoeijt te werden. $\mathrm{Om}$ sulx voor te comen soude meede een sifting noodich weesen van alle openbaare ontrouwe dienaaren, debauchanten, die opspraackelijk van leeven sijn en onbequam tot haar dienst, dewelcke sonder onderscheijt van persoon uijtgeschooten en gedeporteert na 't Vaderlant behoorden gesonden te werden, en daarteegen met ijder bodem dat nootsaaclijck is van hier te senden soodaenige fraeije cooplieden haar boechouders of knegts, die treffelijcke getuugenis door haar trouwe diensten van haar patroonen hadden. Als dit maar een dozijn jaar geobserveert wierd, soude buuten twijfel de Maatschappij in een treffelijcker stant gebragt werden.

Daartoe den Almagtigen Heere van hemel en van aarde sijn milden seegen gelieve te gunnen.

- Kostenbesparing, bezuiniging.

'Schrijvers, klerken; in het algemeen de lagere bureelambtenaren. 